\title{
GEOCHEMICAL AND PETROGRAPHIC EVIDENCE FOR HIGH MG-ULTRAPOTASSIC MAGMAS IN SE COLORADO, USA
}

\author{
Gibson, ${ }^{(1)}$ S.A.; Thompson, ${ }^{(1)}$ R.N.; Mitchell, ${ }^{(2)}$ J.G.; Dickin, ${ }^{(3)}$ A.P.; Morrinson, ${ }^{(4)}$ M.A. \& Hendry, ${ }^{(4)}$ G.L.
}

(1)Department of Geological Sciences, University of Durham, South Road, Durham, DH1 3LE (UK); (2)Department of Physics, The University, Newcastle upon Tyne, NE1 7RU (UK); (3)Department of Geology, McMaster University,

1280 Main Street West, Hamilton, Ontario, L85 4M1 (Canada); (4)School of Earth Sciences, University of Birmingham, Edgbaston, Birmingham, B15 2TT (UK).

Two Buttes, Colorado $\left(37^{\circ} 30^{\prime} \mathrm{N} 102^{\circ} 30^{\prime} \mathrm{W}\right)$ is situated on the stable plateau of the Great Plains, $300 \mathrm{~km}$ east of the present-day axis of the Rio Grande rift. This complex consists of two laccoliths and numerous associated dykes which have intruded sediments of Triassic and Cretaceous age. The laccoliths are cut by sparse late-stage syenitic pegmatite veins and contain crustal xenoliths. Petrographically the rocks comprising the laccoliths consist of phenocrysts of clinopyroxene and phlogopite \pm olivine that are set in a groundmass of feldspar, magnetite, clinopyroxene and phlogopite. Phlogopite mineral separates from these previously undated rocks yielded $\mathrm{K} / \mathrm{Ar}$ ages of $27-35 \mathrm{Ma}$. The Oligocene age of these intrusions corresponds with the initiation of extension and magmatism in the Rio Grande rift and further west. The Two Buttes minettes therefore appear to represent the most easterly outcrop of rift-related magmatism.

The rocks were originally called prowersites by Cross (1906) but have recently been classified as minettes (Bergman, 1987). The Two Buttes intrusions have an ultrapotassic geochemistry $\left(\mathrm{K}_{2} \mathrm{O} / \mathrm{Na}_{2} \mathrm{O}=1.5-3.2\right)$ but have concentrations of $\mathrm{Al}_{2} \mathrm{O}_{3}$ that are too high (12.5-15.8 wt.\%) for the rocks to be classified as lamproites. Concentrations of MgO vary from 4.0-9.6 wt.\% and $\mathrm{SiO}_{2}$ from 50.3-56.8 wt.\%. The Two Buttes minettes are enriched in light rare-earth elements (LREE) relative to heavy rare-earth elements (HREE; $\left.\mathrm{Ce} / \mathrm{Cb}_{\mathrm{n}}=11-19\right)$ and are enriched in large ion lithophile elements (LIL) relative to LREE's $\left(B a / L a^{n}=1-2\right)$. Chondrite-normalised incompatible element diagrams show troughs at $\mathrm{Nb}$ and Ta refative to LREE's (La/Nb $=3-4$ ) and LIL's. In terms of whole-rock geochemistry, the Two Buttes minettes are similar to those in the Navajo Province which lies $200 \mathrm{~km}$ to the west of the Rio Grande rift axis. The minettes at Two Buttes have lower $\mathrm{Ce} / \mathrm{Yb}$ ratios than the minettes from the Navajo Province $\left(\mathrm{Ce} / \mathrm{Yb}_{\mathrm{n}}=36-79\right)$ and have higher concentrations of HREE's for a given MgO content. We suggest that this variation in $\mathrm{Ce} / \mathrm{Mb}$ ratios is due to partial melting, i.e. the minettes at Two Buttes represent a greater degree of partial melting of a garnet bearing mantle than those in the Navajo province.

${ }^{87} \mathrm{Sr} /{ }^{86} \mathrm{Sr}$ ratios for the Two Buttes minettes range from 0.707512 to 0.70842 . These are higher than those opsesve from other western USA ultrapotassics, such as the Leucite Hills and Smoky Butte. ${ }^{43} \mathrm{Nd} /{ }^{44} \mathrm{Nd}$ isotope fatios range from 0.512321 to 0.512392 and show a negative correlation with Sr-isotopes. ${ }^{43} \mathrm{Nd} /{ }^{4} \mathrm{Nd}$ ratios show a positive gorrelation with $\mathrm{MgO}$, i.e. the most evolved minettes have the lowest ${ }^{43} \mathrm{Nd} /{ }^{144} \mathrm{Nd}$ ratios. ${ }^{87} \mathrm{Sr} /{ }^{86} \mathrm{Sr}$ ratios exhibit a corresponding negative correlation with $\mathrm{MgO}$. We integret this in terms of AFC style contamination. The minettes appear to have assimilated ${ }^{8}$ Sr-rich crust during fractionation. The absence of mantle xenoliths within the Two Buttes minettes is consistent with them fractionating in upper-crustal magma chambers. On an Sr, Nd isotope plot the Two Buttes minettes, like the Navajo minettes, trend towards EM2 (Zindler \& Hart, 1986). It has been suggested that an EM2 component is typical of a circumcratonic lithospheric mantle domain, as opposed to the EM1 cratonic domain (Menzies, 1989). However potassic rocks in and around the Rio Grande rift e.g. Spanish Peaks, Elkhead Mountains, appear to have either EM1 or EM2 signatures, implying that the domains are localised. EM1 and EM2 reservoirs may contain a mixture of recycled subducted oceanic crust and sediments. The isotopic compositions of oceanic crust, with either pelagic sediments or terrigenous sediments, are thought to be responsible for the isotope 
chemistry of EM1 and EM2 reservoirs, respectively (Chauvel \& Hofmann, 1990). Relative depletions in $\mathrm{Nb}, \mathrm{Ta}$ and $\mathrm{Ti}$ may: i) represent subduction related magmas or ii) result from the high crystal/liquid distribution coefficients of high-field-strength elements (HFSE) relative to LREE's and LIL's. Meen \& Ayers (1989) and Kelemen et al. (1990) calculated that basaltic magma ascending relatively slowly through lithospheric mantle and reacting with it will develop HFSE depletions. Inversions of REE concentrations of other similar high-Mg K-rich magmas from the western United States (McKenzie \& O'Nions, in press) show that the magma sources are preferentially enriched, relative to chondrite, in the LREE (i.e. La to Sm) rather than the MREE to HREE (i.e. Eu to Lu). They suggest that the magmas were in equilibrium with an amphibole-bearing peridotite and that the enrichment of the source regions was associated with subduction. During extension, enriched mantle regions bearing amphibole would be the first to melt. Unlike the Navajo Province, Two Buttes is situated $300 \mathrm{~km}$ east of the projected limit of the zone effected by Mesozoic and early-Cenozoic eastward subduction of the Farallon Plate (Grand, 1987). Any subduction component within the Two Buttes minettes would have to have been inherited from the underlying accreted Proterozoic island arc-volcanics.

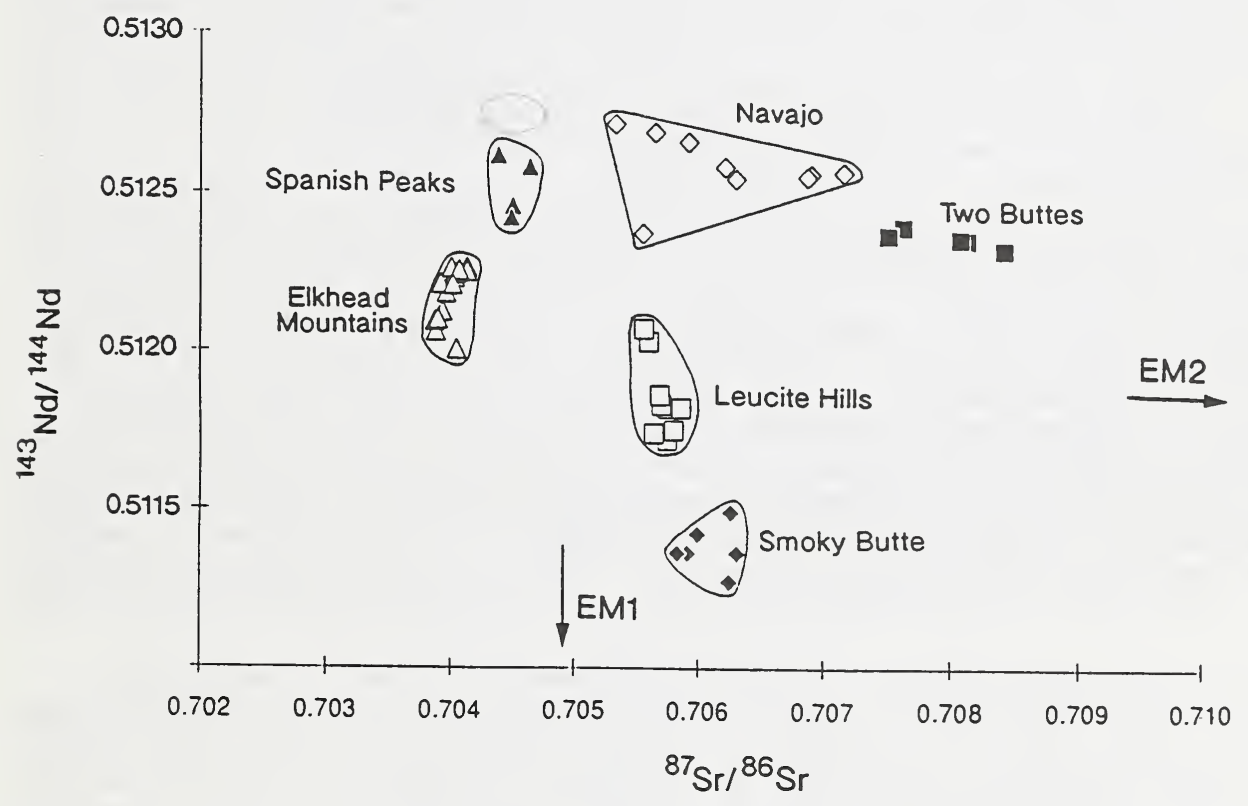

Sr-Nd isotope plot of high-Mg ultrapotassic magmas in the Western United States. Sources of data are as follows: Elkhead Mountains, Leat et al., 1988; Leucite Hills and Smoky Butte, Fraser, 1987; Navajo, Alibert et al., 1986 and our unpublished data; Spanish Peaks and Two Buttes, our unpublished data.

\section{References.}

Alibert, C., Michard, A. \& Albarede, F., 1986. Isotope and trace element geochemistry of Colorado Plateau volcanics. Geochimica et Cosmochimica Acta, 50, 2735-2750.

Bergmann, S.C., 1987. Lamproites and other potassium-rich igneous rocks: a review of their occurrence, mineralogy and geochemistry. In Fitton, J.G \& Upton, B J., (ed.s) Alkaline Igneous Rocks, Special Publication of the Geological Society of London, 30. . Cross, W. 1906. Prowersose (syenitic lamprophyre) from Two Buttes, Colorado. Journal of Geology, 1906, 165-172. 
Chauvel, C. \& Hofmann, A.W., 1990. The HIMU-EM connection. International Volcanological Congress (Abstracts).

Fraser, K. J., 1987. Petrogenesis of kimberlites from South Africa and lamproites from western Australia and North America. Unpublished Ph.D thesis, Open University. Grand, S.J., 1987. Tomographic inversion for shear velocity beneath the North American plate. Journal of Geophysical Research, 92, 14065-14090.

Kelemen, P.B., Johnson, K.T.M., Kinzler, R.J., \& Irving, A.J., 1990. High-field-strength element depletions in arc basalts due to mantle-magma interaction. Nature, 345, 521-524. Meen, J.K. \& Ayers, J.C., 1989. Cryptic metasomatism and creation of melts with depleted contents of the high-field-strength elements: coupled effects due to infiltration of melt in harzburgite. In Continental magmatism (abstracts). New Mexico Bureau of Mines and Mineral Resources Bulletin, 131, 185.

McKenzie, D.P. \& O'Nioins, R.K., in press. Partial melt distributions from inversion of rare-earth element concentrations. Journal of Petrology.

Leat, P.T., Thompson, R.N., Morrison, M.A., Hendry, G.L. \& Dickin, A.P., 1988. Silicic magmas derived by fractional crystallisation from Miocene minette, Elkhead mountains, Colorado. Mineralogical Magazine, 52, 577-585.

Zindler, A. \& Hart, S., 1986. Chemical Geodynamics. Annual Review Earth and Planetary Science Letters, 14, 493-571. 